\title{
ЗВОРОТНИЙ БІК РЕФОРМИ КРИМІНАЛЬНОГО СУДОЧИНСТВА
}

\author{
Копіца О. В., Смоков С. М.
}

У статmі йдеться про негативні наслідки, що їх спричинили реформи кримінального судочинства, зокрема й про введення в дію Кримінального прочесуального кодексу України 2012 р., люстрацію, реформування органів національної поліціі (міліціі), органів прокуратури та судових органів. Зокрема, зосереджено увагу на подіях, які були пов'язані 3 тиском на суддів Апеляційного суду одеської області та діями Одеської обласної прокуратури із цього приводу. У статті також пропонуються зміни до чинного КПК України.

Ключові слова: реформування, кримінальне судочинство, прокуратура, суд.

В статье идет речь о негативных последствиях, которые стали возможными вследствие реформы уголовного судопроизводства, в частности о введении в действие уголовного процессуального кодекса Украины 2012 г., люстрации, реформировании органов национальной полиции Украины (милиции), органов прокуратуры и судебных органов. Сосредоточено внимание на событиях, которые были связаны с давлением на судей Апелляционного суда Одесской области и действиями Одесской областной прокуратуры по этому поводу. В статье также предлагаются изменения в действующий УПК Украины.

Ключевые слова: реформирование, уголовное судопроизводство, прокуратура, суд.

In the article there were described the negative consequences caused by criminal justice reforms, especially coming into force of the Criminal Procedure Code of Ukraine in 2012 and a great number of changes which were brought into $i t$, during the so-called procedural reform of 2017, lustration, the reformation of the National Police, which has led to a huge loading on investigative units of the National Police where criminal proceedings have been in no motion for a long time and not any investigative actions were carried out on them, even there was revealed the person who committed the crime.

It was stated that the lack of a professional nucleus in the investigative units, the study of evidence directly only in the court, gave a rise to the phenomenon of non initiative while collecting the evidence at the pre-trial investigation. In the article also was said that cases in the courts are even worse: the number of court premises after the so-called judicial reform has been completely closed due to the lack of judges, in some parts of the courts, only one or two judges were left, which makes it impossible to set up a court to hear criminal proceedings required by law.

Judges continue to be slammed by various "activists": they disrupt court hearings, insult the judges, provoke the force using, threaten the judges and their relatives. It happens on the one hand and on the other is the state power which instead of providing normal working conditions for judges and protecting them from attacks, creates a situation for them that hinders the impartiality of justice.

At the same time forgetting that one of the constituents of the status of a judge is his independence and integrity, which determines the classification of judges in a separate category of persons. Particular attention was paid to the events related to

Копіца О. В., Смоков С. М., 2019 the pressure on judges of the Court of Appeal of Odessa Region and to the actions of the Odessa Regional Prosecutor's Office in this regard. In this respect, the article also proposes changes to the current CPC of Ukraine.

Key words: reformation, criminal proceeding, prosecution, court.

Постановка проблеми та іï актуальність. Сьогодні лише ледачий не критикує правоохоронні і судові органи України. Негативні відгуки про роботу цих систем лунають майже на всіх телеканалах України, у пресі, із трибуни Верховної Ради. Критикують і ті, хто стикалися з правоохоронною системою і судовою владою, i тi, хто навіть жодного разу там не були, а знають все тільки з тих же засобів масової інформації. у чому ж причини такої зневаги до всієї системи правоохоронних органів і судової влади? Причин декілька. Вони накладаються одна на одну. Про реформування кримінального процесуального законодавства вже йшлося давно, а саме з моменту отримання незалежності Україною. Відтоді було розроблено більше десятка проєктів Кримінального процесуального кодексу України. Одні з них були предметом гарячих дискусій серед учених i практичних працівників, інші так і не були винесені на загальне обговорення.

Метою статті $\epsilon$ розгляд негативних наслідків, що їх спричинили реформи кримінального судочинства.

Виклад основного матеріалу. У квітні 2012 р. Кримінальний процесуальний кодекс України (далі - КПК) [1] був прийнятий, а 20 листопада 2012 р. він вступив у дію. Ми не будемо в цій статті обговорювати численні зміни, які за 6 років були внесені до КПК, і конкретні статті самого кодексу, адже про це ми писали в інших наших публікаціях. У цій статті мова піде про жахливі наслідки, які це реформування спричинило. Першою руйнівною силою, яка почала ламати кримінальне судочинство, став новий КПК.

У перші роки кодекс зазнавав своєрідної обкатки: його випробовували на міцність, справедливість, узгодженість історона захисту, і сторона обвинувачення, і суди. У результаті, звичайно, було виявлено чимало недоліків. Проте до 2014 р. до нового кодексу суттєвих змін не вносилось, а виявлені вади лише обговорювалися в науковому середовищі, а також серед практиків.

Натомість із 2014 р. ситуація кардинально змінилася. Відтоді було ухвалено майже 60 законів, якими вносилися зміни та доповнення до КПК. Найбільш резонансні закони ухвалювалися під час так званої процесуальної реформи 2017 р. На жаль, ці зміни нерідко виглядають сирими, недопрацьованими та непродуманими. Іноді здається, що черговий проєкт змін до КПК пропонується не з метою вдосконалення кримінального процесуального законодавства й усунення його недоліків та суперечностей, а під якусь конкретну ситуацію, конкретне кримінальне провадження, для конкретної особи. Часто це призводить до того, що норма, яку 
похапцем внесли до кодексу під цю конкретну ситуацію, не узгоджується з іншими нормами КПК і суміжними законами або ж викладена у такий спосіб, що їі можна розуміти так, як заманеться будь-кому [2].

Як правильно зазначає професор Б.Г. Розовський, «при конструюванні норм права і подальшому відправленні правосуддя за буквою закону з поля зору законодавців, суддів і учасників процесу рангом нижче випала людина» [3].

Другою руйнівною силою, на наш погляд, стало так зване реформування системи правоохоронних органів. Ми не будемо зараз обговорювати проблеми патрульної поліції, а поведемо мову про професійні кадри МВС, які протидіють злочинності. Зокрема, це оперативні підрозділи та органи досудового розслідування. І якщо до нового КПК вони якось ще пристосувались, то масові звільнення під благородним гаслом боротьби з корупцію призвели до того, що на місце професійно підготовлених правоохоронців прийшли особи за оголошенням, яких за моральними, професійними і діловими якостями до цієї системи не можна було допускати і на гарматний постріл. Такі особи стали працювати не тільки у патрульній поліції, але й зайняли посади в оперативних підрозділах, посади слідчих, керівників районних відділів поліції. Усе це разом із новим КПК породило колапс із виявленням, розкриттям та розслідуванням кримінальних правопорушень.

Так, у слідчих підрозділах Національної поліції сьогодні згідно з різними оцінками навантаження на одного слідчого становить від 90 до 500 кримінальних проваджень. При такому завантаженні про жодні якісні показники не може йтися, кримінальні провадження лежать без руху, не проводяться слідчі дії, навіть якщо встановлено осіб, які вчинили злочини. Запобіжні заходи відносно підозрюваних обираються вкрай рідко, а такі запобіжні заходи, як тримання під вартою та затримання підозрюваного в порядку ст. 208 КПК, майже не застосовуються. Одна з причин цього явища, як пояснили процесуальні керівники, полягає в тому, що якщо слідчий суддя не задовольнить клопотання про обрання запобіжного заходу, зокрема тримання під вартою, після затримання підозрюваного, то прокурора, який здійснював процесуальне керівництво, позбавлять премії, а це майже половина його заробітної платні. Відсутність професійного ядра в слідчих підрозділах, новий КПК, дослідження доказів безпосередньо тільки в суді породили явище безініціативності під час збирання доказів у рамках досудового розслідування. Вони потрібні тільки для прийняття проміжних рішень на етапі досудового розслідування і фактично не впливають на остаточне рішення суду у справі, тому в суді взагалі не досліджуються.

Як слушно зазначає професор Б.Г. Розовський, «історично розслідування зводилось до активного протиборства слідчого з обвинуваченим. Мені соромно бачити, як відбувається глобальна гіперболізація прав i свобод громадян, трансформувавшись у систему правосуддя, як знизила потенціал свого застосування НСРД, практично виключивши підозрюваного і обвинуваченого із числа джерел інформації про вчинений злочин. Під абсолютно недійсним приводом захисту від тортур вони наділяються правом відмовитись від давання показань. Це реально виключило застосування напрацьованої століттями криміналістичної тактики ефективного допиту. Абсурд очевидний. Правосуддя втратило можливість отримувати більш достовірну картину злочину і робити об'єктивну оцінку ступеня вини особи, яка його вчинила» [3].

У зв'язку із цим велика кількість кримінальних проваджень, де $є$ реальні підозрювані, так і залишається не доведеною до кінця через брак доказів.

А що ж судова влада? Тут справи ще гірші: деякі приміщення судів після так званої судової реформи зовсім зачинені через відсутність суддів, у частині судів залишилось по один-два судді, що унеможливлює створення складу суду для розгляду кримінальних проваджень, як того вимагає закон. Суддів продовжують шельмувати різні активісти, які зривають судові засідання, ображають суддів, провокують на застосування сили, вдаються до погроз як суддям, так і їхнім близьким. Яскравий тому приклад - бійка 23 листопада 2018 р. у Приморському суді м. Одеса, яку вчинили завезені з Вінниці та інших міст активісти. Це спричинило зрив і перенесення судового засідання по резонансному кримінальному провадженню.

Крім того, державна влада замість забезпечення нормальних умов роботи для суддів та захисту їх від нападів сама створює таку обстановку, яка заважає неупереджено відправляти правосуддя, забуваючи при цьому, що однією зі складових частин статусу судді $\epsilon$ його незалежність та недоторканність, що зумовлює віднесення суддів до окремої категорії осіб. М.А. Погорецький $з$ цього приводу зазначає: «Недоторканність суддів - один з елементів їхнього статусу, вона не $\epsilon$ їнім особистим привілеєм, а має публічно-правове призначення, яке полягає у тому, щоб забезпечити здійснення правосуддя неупередженим, безстороннім і справедливим судом» [4, с. 60].

Згідно з приписами статей 126, 129 Конституції України незалежність і недоторканність судді гарантовані Конституцією і законами України. Вплив на суддю в будьякий спосіб забороняється. Суддя, здійснюючи правосуддя, єнезалежнимтакеруєтьсяверховенствомправа[5].

Умови виконання професійних обов'язків суддів i правові засоби, за допомогою яких забезпечується реалізація конституційних гарантій їхньої самостійності та незалежності, визначені Законом України «Про судоустрій і статус суддів» [6].

Відповідно до положень ст. 6 Закону України «Про судоустрій і статус суддів», здійснюючи правосуддя, суди $\epsilon$ незалежними від будь-якого незаконного впливу. Суди здійснюють правосуддя на основі Конституції і законів України та на засадах верховенства права. Втручання в здійснення правосуддя, вплив на суд або суддів у будь-який спосіб, неповага до суду чи суддів, збирання, зберігання, використання і поширення інформації усно, письмово або в інший спосіб із метою дискредитації суду або впливу на безсторонність суду, заклики до невиконання судових рішень забороняються і мають наслідком відповідальність, установлену законом. Органи державної влади та органи місцевого самоврядування, їх посадові особи повинні утримуватися від заяв та дій, що можуть підірвати незалежність судової влади.

Згідно зі ст. 48 зазначеного Закону суддя у своїй діяльності щодо здійснення правосуддя $є$ незалежним від будь-якого незаконного впливу, тиску або втручання. Суддя здійснює правосуддя на основі Конститу- 
ції і законів України, керуючись при цьому принципом верховенства права. Втручання в діяльність судді щодо здійснення правосуддя забороняється і має наслідком відповідальність, установлену законом.

Ми навели цілу низку законодавчих актів, які повинні захищати суддів. Але що ж відбувається насправді?

Прокуратура України в особі Генерального прокурора, його заступників, а також прокурорів нижчих ланок порушує кримінальні провадження за постановлення суддями завідомо неправосудного судового рішення згідно зі ст. 375 КК. І це ще до того, як таке рішення, з яким не погоджується сторона обвинувачення, оскаржується в установленому законом порядку до суду вищої ланки.

Згідно 3 даними Генеральної прокуратури України протягом 2017 р. було зареєстровано 517 кримінальних проваджень за ст. 375 КК (за фактами постановлення суддями завідомо неправосудного вироку, ухвали або постанови). У 2016 р. було зареєстровано 374 таких провадження, у 2015 р. - 388, у 2014 р. - 220. Із зазначених 517 проваджень було закрито 232, натомість лише 6 проваджень з обвинувальними актами було направлено до суду [7].

Здебільшого прокурорами вносяться відомості до ЄРДР виключно щодо суддів, які прийняли рішення в кримінальних провадженнях не на користь сторони обвинувачення. Такі кримінальні провадження були зареєстровані відносно суддів у справах Лозінського, Кернеса, Лесика та інших. При цьому в м. Одеса слідчі прокуратури Одеської області в останні дні своїх повноважень внесли дванадцять відомостей до ЄРДР відносно всіх суддів судової палати з розгляду кримінальних справ Апеляційного суду Одеської області за ч.ч. 1, 2 ст. 375 КК. Також дивує те, що практично всі вони були зареєстровані 17.11.2017 р. за зверненнями громадян, які не були учасниками (сторонами) кримінальних проваджень, які перебували в провадженні зазначеного суду.

Окремо слід звернути увагу на те, що за дивним збігом обставин так звані заявники звернулися майже одночасно зі зверненнями виключно до прокуратури Одеської області (не до інших правоохоронних органів) в останній робочий день перед припиненням повноважень органів прокуратури щодо здійснення досудового розслідування злочинів, підслідних ДБР.

Також виникають обґрунтовані сумніви щодо існування вказаних громадян та подання саме ними звернень, оскільки станом на 31.07.2018 р., тобто упродовж понад 8 місяців із моменту внесення відомостей до ЄРДР, слідчими прокуратури Одеської області не встановлені і не допитані особи, які $\epsilon$ заявниками, а зазначені у зверненнях судові рішення не витребувані.

Викладені вище факти безпідставного внесення посадовими особами прокуратури Одеської області до ЄРДР відомостей про вчинення суддями палати з розгляду кримінальних справ Апеляційного суду Одеської області злочинів, передбачених ч.ч.1, 2 ст. 375 КК, $\epsilon$ прикладами безпосереднього втручання у діяльність суддів та тиску на них із метою спонукання до прийняття потрібних правоохоронним органам рішень, зокрема і при розгляді клопотань про надання дозволів на проведення негласних слідчих розшукових дій. Майже за рік, тобто у жовтні 2018 р., всі ці провадження були закриті за ч. 2 ст. 284 КПК. Р. Чимний з цього приводу зазначив: «Будь-які сумніви в об'єктивності чи винуватості суддів кидають тінь на суд, але ця палиця має два кінці: неякісні дії прокуратури кидають тінь і на суд, і на органи прокуратури» [8].

3 огляду на викладені обставини 14.08.2018 р. всі судді палати з розгляду кримінальних справ Апеляційного суду Одеської області звернулися з повідомленням до Вищої ради правосуддя про втручання в їхню діяльність як суддів щодо здійснення правосуддя для вжиття відповідних заходів реагування. Згодом рішенням Вищої ради правосуддя №3157/0/15-18 від 18.10.2018 р. було внесено до Генеральної прокуратури України подання про виявлення та притягнення до встановленої законом відповідальності осіб, які допустили бездіяльність, що порушує гарантії незалежності суддів Апеляційного суду Одеської області [9].

Сподіваємося на адекватну реакцію Вищої ради правосуддя на зазначене подання та вжиття реальних заходів Генеральною прокуратурою України щодо недопущення подальшого втручання в діяльність суддів та тиску на них.

Отже, правоохоронні органи здійснювали досудове розслідування кримінальних проваджень, у яких дії суддів щодо відправлення правосуддя оцінювалися поза передбаченими законом процедурами апеляційного оскарження, тобто незаконно. Як правило, у таких кримінальних провадженнях суддів викликають для давання пояснень, допиту як свідків також і щодо вчинюваних ними під час розгляду справ процесуальних дій та прийнятих рішень, що грубо порушує основні гарантії незалежності суддів.

Прокурору дозволено вчиняти процесуальні дії та подавати клопотання судді згідно із законом, а також викладати фактичні обставини в справі та надавати юридичне обґрунтування своїх дій, але прокурор не може втручатись у будь-який спосібу процес прийняття суддею рішення і повинен дотримуватися судових рішень [10].

Нам здається, що це було зроблено з метою тиску, створення обстановки залякування i напруження, а також для утворення перешкод при проходженні кваліфікаційного оцінювання суддями Апеляційного суду Одеської області.

Як зазначено в пункті 19 Рекомендації Rec (2000) 19 КомітетуміністрівРадиєвропидержавам-членамщодо ролі прокуратури в системі кримінального правосуддя, прокурори повинні поважати незалежність і неупередженість суддів. Вони ніколи не повинні ані ставити під сумнів судові рішення, ані перешкоджати їх виконанню, гарантуючи використання їхнього права на процедуру апеляції або на будь-яку іншу пояснювальну процедуру.

Відповідно до ч. 6 ст. 48 Закону України «Про судоустрій і статус суддів» органи державної влади, органи місцевого самоврядування, їх посадові та службові особи і їх об'єднання зобов'язані поважати незалежність судді і не зазіхати на неї.

Згідно з правилами ч. 4 ст. 48 та п. 9 ч. 7 ст. 56 Закону України «Про судоустрій і статус суддів» суддя зобов'язаний звертатися з повідомленням про втручання в його діяльність як судді щодо здійснення правосуддя до Вищої ради правосуддя та до Генерального прокурора упродовж п'яти днів після того, як йому стало відомо про таке втручання. Так, у 2017 р. до Вищої ради правосуддя надійшло 330 звернень від суддів про втручання в їхню діяльність, а у 2018 р. таких звернень було вже 434 [11]. 
Відповідно до ч. 9 ст. 1 Закону України «Про Вищу раду правосуддя» Вища рада правосуддя вживає заходів щодо забезпечення авторитету правосуддя та незалежності суддів. Згідно з правилами ст. 73 вказаного Закону Вища рада правосуддя з метою забезпечення незалежності суддів та авторитету правосуддя, зокрема, вносить до відповідних органів чи посадових осіб подання про виявлення та притягнення до встановленої законом відповідальності осіб, якими вчинено дії або допущено бездіяльність, що порушує гарантії незалежності суддів або підриває авторитет правосуддя, вживає інших заходів, які $\epsilon$ необхідними для забезпечення незалежності суддів та авторитету правосуддя.

Відповідно до пунктів 1 та 2 Основних принципів незалежності судових органів, схвалених резолюціями 40/32 та 40/146 Генеральної Асамблеї ООН від 29 листопада та 13 грудня 1985 р., незалежність судових органів гарантується державою та закріплюється в конституції або законах країни. Усі державні та інші установи зобов'язані поважати незалежність судових органів та дотримуватися їі. Судові органи вирішують передані їм справи безсторонньо, на основі фактів та відповідно до закону і без будь-яких обмежень, неправомірного впливу, спонуки, тиску, погроз або втручання (прямого чи непрямого) з будь-якого боку і з будь-яких причин.

І тільки суд вищої інстанції має право, скасовуючи рішення суду нижчої інстанції, висловити свою думку відносно того, чи справедливий вирок виніс суддя, та надати цьому правову оцінку. Коментуючи рішення суддів, виконавча та законодавча влада мають уникати критики, яка може підірвати незалежність судової влади або довіру суспільства до неї. Їм також слід уникати дій, які можуть поставити під сумнів їхнє бажання виконувати рішення суддів, за винятком випадків, коли вони мають намір подати апеляцію [12].

Європейський суд з прав людини підкреслив, що судовий обсяг зобов'язань у розумінні п. 1 ст. 6 Конвенції не обмежується судовою гілкою влади. Цей обсяг зобов'язань також покладає обов'язки на виконавчі, законодавчі та будь-які інші органи держави незалежно від їх рівня поважати та виконувати рішення та постанови судів, навіть якщо ці органи не погоджуються 3 ними. Отже, повага з боку держави до повноважень судів $\epsilon$ невід' $є$ мною передумовою впевненості суспільства в судах, а також у верховенстві закону. Щоб це відбулося, конституційних гарантій незалежності та неупередженості судової гілки влади замало. Ці гарантії мають бути ефективно впроваджені в повсякденну поведінку та поводження органів влади [13].

Також ці гарантії мають бути відображені й у законодавстві. Так, член Вищої ради правосуддя О. Маловацький у своєму інтерв'ю зазначив: «Можливо, щоб система стримувань і противаг запрацювала, доведеться вносити зміни до законодавства. На жаль, сьогодні порушити досить легко. Достатньо будь-якого звернення про вчинення кримінального правопорушення» [8].

Висновки. 3 огляду на наведене ми пропонуємо внести зміни до ст. 214 КПК, доповнивши їі ч. 7-1 такого змісту: «Якщо вирішується питання про внесення до ЄРДР відомостей стосовно судді про вчинення кримінального правопорушення, передбаченого ст. 375 КК України, то право внесення таких відомостей до ЄРДР має виключно Генеральний прокурор України або його заступники, а також Директор Державного бюро розслідувань».

\section{Література}

1. Кримінальний процесуальний кодекс України : закон України від 13.04.2012 р. № 4651-VI. URL: http://zakon.rada.gov.ua.

2. Зворотній бік сирих реформ / В. Фаринник, Н. Головко, Є. Олефіренко. Закон і бізнес. 2018. № 48. 1-7 грудня. С. 12.

3. Розовский Б.Г. Мне стыдно быть юристом. Економіка та право. 2018. № 1. С. 163-183.

4. Погорецький М.А., Гринюк В.О. Повідомлення судді про підозру: проблемні питання правового регулювання, теорії та практики. Вісник кримінального судочинства. № 2. 2018. С. 58-71.

5. Конституція України : Закон України від 28.06.1996 p. № 254к/96-ВР із змін., внес. згідно із Законами України та Рішеннями Конституційного Суду : станом на 30.09.2016 p. № 1401-VIII. URL: http: / /zakon.rada.gov.ua.

6. Про судоустрій і статус суддів : Закон України від 02.06.2016 р. № 1402-VIII із змін., внес. згідно із Законами України : станом на 05.08.2018 р. № 2509-VIII. URL: http: / /zakon.rada.gov.ua.

7. Статистична інформація Генеральної прокуратури України за 2017 рік. URL: http: / /www.gp.gov.ua.

8. Чимний Р. Сьогодні в суспільстві панує така собі презумпція винуватості судді. Закон і бізнес. 2018. № 28. 14-20 липня. С. 4-5.

9. Про продовження строку тимчасового відсторонення судді Рокитнянського районного суду Київської області Нечепоренка Л.М. від здійснення правосуддя у зв'язку з притягненням до кримінальної відповідальності : рішення Вищої ради правосуддя від 18.10.2018 р. № 3157/0/15-18. URL: http: //vru.gov.ua.

10. Про відносини між суддями та прокурорами в демократичному суспільстві : висновок Консультативної ради Європейських суддів № 12 (2009) ; висновок Консультативної ради Європейських прокурорів № 4 (2009). URL: http://www.viaduk.net.

11. Реєстр повідомлень суддів про втручання в діяльність судді щодо здійснення правосуддя 2016-2018 pp. URL: http://www.vru.gov.ua.

12. Основні принципи незалежності судових органів : схвалені резолюціями 40/32 та 40/146 Генеральної Асамблеї ООН : станом на 18.12.1985 р. № 995_201. URL: http://zakon.rada.gov.ua.

13. Справа «Агрокомплекс проти України» : рішення Європейського суду з прав людини від 25.07.2013 р. № 974_973. URL: http: / / zakon.rada.gov.ua.

Koniua O. B., кандидат юридичних наук, доцент, суддя Одеського апеляційного суду

Смоков С. М., кандидат юридичних наук, професор, професор кафедри кримінального процесу Одеського державного університету внутрішніх справ 